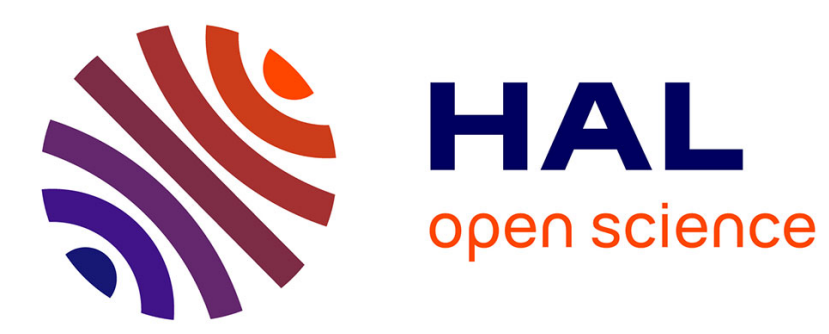

\title{
Does Policing the Risk Society Hold the Road Risk?
}

Jérôme Ferret, Vincent Spenlehauer

\section{To cite this version:}

Jérôme Ferret, Vincent Spenlehauer. Does Policing the Risk Society Hold the Road Risk?. British Journal of Criminology, 2008, 49 (2), pp.150-164. 10.1093/bjc/azn066 . hal-01954181

\section{HAL Id: hal-01954181 \\ https://hal-enpc.archives-ouvertes.fr/hal-01954181}

Submitted on 13 Dec 2018

HAL is a multi-disciplinary open access archive for the deposit and dissemination of scientific research documents, whether they are published or not. The documents may come from teaching and research institutions in France or abroad, or from public or private research centers.
L'archive ouverte pluridisciplinaire HAL, est destinée au dépôt et à la diffusion de documents scientifiques de niveau recherche, publiés ou non, émanant des établissements d'enseignement et de recherche français ou étrangers, des laboratoires publics ou privés. 


\title{
DOES POLICING THE RISK SOCIETY HOLD THE ROAD RISK?
}

\author{
JÉrôme Ferret ${ }^{\dagger}$ and Vincent SPEnlehauer*
}

Ericson and Haggerty's book, Policing the Risk Society (1997), sets out to annul Bittner's classical, coercion-based reading of the police and replace it with a radically new paradigm that foregrounds the panoptical or knowledge work dimension of the police and its potential to serve the interests of non-police social-disciplinary institutions. In this article, we test this neo-Foucauldian paradigm on the basis of a body of research into road traffic policing. As a result, we observe that though nonpolice owner-managers of new risks challenge the societal immanence, centrality and publicness of police organizations, with time, these challenges fail. We therefore argue that Ericson and Haggerty's notion of panoptical policing should be taken as a theoretical innovation, which, far from eliminating Bittner's paradigm, enhances it with a new force.

\section{Introduction}

Ericson's and Haggerty's 1997 book, Policing the Risk Society (hereafter EH), represents a formidable epistemological gamble: one which, if successful, would be a watershed in the social sciences of policing, for it would mean the supplanting of the classical Egon Bittner (1970) model. Let us recall that Bittner defines the role of the police in modern societies as a mechanism for the distribution of non-negotiable force-given that (and this is very important) the police are characterized less by their actual use of violence than by their virtual capacity to master all private use of such violence (Monjardet 1996; Brodeur 2003). And, in spite of the endless attacks it has been subjected to since its publication (Ocqueteau 2004), Bittner's thesis appears to resist all attempts at falsification. But does it? Maybe not in the case of EH.

Taking advantage of the dissension regarding the risk society caused by the work of Ulrich Beck ${ }^{1}$ (2001), EH set out to annul Bittner's classical, coercion-based reading and replace it with a radically new paradigm: one that foregrounds the role of the police in the production and processing of information and expert knowledge-they invoke Bruno Latour's (1987) concept of the 'centre of calculation'-for public or private non-

\footnotetext{
* Mastère d'action publique, Ecole nationale des ponts et chaussées, 6-8 avenue Blaise pascal 77455 Champs-sur-Marne Cedex 2 France; vincent.spenlehauer@enpc.fr.

${ }^{\dagger}$ LEREPS/CIRESS, University of Toulouse 1, University of Toulouse, France.

${ }^{1}$ To sum Beck up briefly, the risk society is characterized by the significant and increasing role of organized social practices-in science, economics, industry and politics-intended to increase our knowledge, and thus our control and distribution, of the risks 'modern' scientific and technological development has either concretely caused or brought to the attention of our societies via the 'off-territorialization' effects so brilliantly adduced by Anthony Giddens. The extent of these organized social practices thrusts human societies into a 'second modernity' or, to put it more precisely, into the age of reflexive modernity.
} 
police institutions. ${ }^{2}$ We see it as important to note the opening up of this new interpretative network and discuss it in depth in the light of empirical findings. It is not a matter here of establishing a validation or a definitive overall refutation. Rather, we intend to take advantage of the opportunity provided by the two authors to suggest other cumulative avenues; and this would have been impossible without the shockwave generated by EH's book, the great merit of which is that it decompartmentalizes the policing entity by setting it at the core of a society placed at risk. The constructive testing we propose is based on a body of inductive, diachronic and/or synchronic research into 'road risk policing' (Carnis et al. 2006; Hamelin and Spenlehauer 2005b), which we have carried out with a small number of close colleagues around the world - in the United States, Quebec, the United Kingdom, France, Spain, Australia and New Zealand. ${ }^{3}$

To shrink the thought-provoking notion of 'policing the risk society' to that of 'policing the road risk society' presents at least three advantages. The first has to do with the fact that road risk 'consumes' a great deal of police effort. It is currently estimated that, in the OECD countries, some 10-20 per cent of police manpower resources go into policing the roads. The California Highway Patrol alone accounts for 13 per cent of police numbers for the entire state. In New Zealand, the Road Policing Branch of the single national police force represents a quarter of the force's budget. ${ }^{4}$ In other words, then, in the world of policing, the road risk police can in no way be considered a minority entity. On the contrary, it is a large-looming one and, moreover, a continuous, stable feature of police histories.

This brings us to the second advantage: the road risk society and its policing have considerable historical and geographical thickness. In America, the beginnings of the road risk society (RRS) can be dated roughly to the advent of the famous Model T Ford in 1910. In Europe, Australia and Japan, the process came about later and less suddenly. But, whatever the circumstances, observation of all industrialized nations everywhere reveals a period of at least 50 years during which police organizations (PO) evolved in response to the road risk, and allows us to discern general, 'off-territorial' trends and patterns. Study of road risk policing represents a broad and substantial empirical input into the innovative ideas initiated by $\mathrm{EH}$.

\footnotetext{
${ }^{2}$ Comparing Bittner's and EH's respective theories of police might seem rather daring in many respects: for obvious reasons, Bittner has not been in position to situate his thought in relation to the social theory of (proliferating social-constructed) risks, to the fortuitous exception of the dangerous classes risk, which is central to Bittner; Bittner's ethno-methodological approach has nothing in common with EH's ambition to go beyond police studies in order to contribute to critical social theories, etc. It remains that since Bittner's model has been somehow dominant within police studies the three last decades, its evocation could usefully bring out the innovative strength of EH's model. For instance, when EH insist on the capital knowledge work dimension of police in the risk society, they imply that Bittner exaggerated the cardinality of the police as a mechanism of potential distribution of nonnegotiable force within society. For an interesting and more developed comparison of Bittner and EH, see Brodeur (2001).

${ }^{3}$ In addition to the two authors, this small informal research network comprises: Laurent Carnis, Fabrice Hamelin, Anne Kletzlen, Claudine Pérez-Diaz and Anaïk Purenne. Traffic policing was apprehended through various angles: institutional, functional, professional, historical, etc. The methods of inquiry used for on-site fieldwork are: interviews, data-mining, administrative (i.e. annual reports, peer reviews, etc.) and academic (scarce) literature and archives studying, press review, (participative) observation of operations, etc. As an example, two researchers spent (two plus two) weeks in New Zealand and one researcher spent three months in Montreal studying the municipal traffic policing in this city. All costs considered in this research 'programme' amounted to around 700,000 Euros. A large part of the academic output of this research investment can be found in the References.

${ }^{4}$ 'Mother, What Did Policemen Do When There Weren't Any Motors?' is the jokey but unerring title of an article by British historian, Clive Emsley (1991).
} 
Lastly, the third advantage of focusing on road risk policing stems from its early and deep globalization (Kellens and Pérez-Diaz 1997). Challenging EH's (implicitly) universal theory on risk society policing raises the methodological difficulty for the challengers of putting forward evidences and counter-evidences drawn from very different historical and/or regional contexts. ${ }^{5}$ However, and fortunately, shall we say, in the road policing domain, local actors have often thought and still often think global! For instance, the diffusion of speed-camera systems from the early 1990s (for instance, in the state of Victoria in Australia) until now (France began to invest in such technology in 2003) resembles a success story of international 'policy transfer' that circumvented what was seen on regional scenes as untouchable law principles (i.e. the necessary presence, in France or Great Britain, of a police officer when a speeding infringement occurs). Slightly anticipating on what follows, it can also be noted that, at the end of the 1940s, the French private insurance companies owed their economic survival ${ }^{6}$ to their well inspired imitation of the way American insurers had commenced to 'exploit' the road accidents risk after the First World War (Hamelin and Spenlehauer 2008 ; OECD 1990). Concisely, the examples that our argument draws on relate to issues and practices at stake in similar terms within most of the road risk policing milieus of OECD countries. $^{7}$

\section{Policing the Risk Society and Policing the Road Risk Society: First Test}

In this first test, we intend to analyse in historical depth the development of road risk policing in the United States and the history of the interaction between the POs concerned and the environment of the public and private owners of road risks.

\section{Clear evidence of police 'riskification'}

In a first approximation, we shall model the changes within POs in respect of the emergence of a road risk society according to a simple three-part sequence:

(1) Historically and geographically situated socio-technical phenomena (i.e. the Ford T in the United States) cause the appearance of road risks in a given governed part of the world.

(2) Social and/or interest groups (car manufacturers, for instance) socially reconstruct these road risks (Hacking 2000; Bardet 2008) so as ultimately to pressure the POs to 'help' them manage and control the risks to their own advantage.

(3) To meet these pressing demands, police organizations evolve into road risk 'centres of calculation'.

An eloquent illustration of this process is provided by the way in which American insurance companies and automobile manufacturers joined forces in the early 1920s,

\footnotetext{
${ }^{5}$ This difficulty gets aggravated when one writes an article of limited size. For in-depth context analysis and comparison (internationally and diachronically) concerning most of the evidences invoked here, cf. Carnis et al. (2005), Ferret et al. (2007), and issue 58(3)/2005, entitled 'Polices et "policing" de la route: un nouveau regard sur la sécurité' of the French journal devoted to police, Les cahiers de la sécurité intérieure.

${ }^{6}$ The creation of social security in 1946 went de jure with the nationalization of occupational accidents' insurance.

${ }^{7}$ Of course, some regional or historical curiosities remain, but we did not consider them here, since our objective consists of challenging EH's 'off-territorial' theory.
} 
using the National Safety Council (NSC) - an NGO still functioning today - to put road accident injuries on the policy agenda of municipalities and counties, and of their police forces in particular (Bernardin 2006; Hamelin 2006). The aim was to set up a road accident insurance industry to take advantage of the enormous potential created by the rise of the car. This made it essential that the accident risk be known and measured, and the solution opted for was that of convincing local authorities to order their police forces to document the risk in a 'Taylorized' (i.e. systematic and uniform) way in all parts of the country. In this way, the insurance companies were able to pass on to the public sector the prohibitive expense of assessing this specific road risk. Subjection of local police forces to the knowledge requirements of the insurance companies crossed a decisive institutional threshold in 1934, when the NSC founded the NUTI, the Northwestern University Traffic Institute (McEnnis 1952). This was where the future chiefs of local traffic police units were trained, and this training was financed by scholarships from the insurance groups and the automobile industry. This situation, then, confirms the three interlocking theses advanced by EH: transformation of police organizations and police work in response to the emergence of a new risk; a move towards greater knowledge work in police activity; and the upstream formatting and Taylorization of police knowledge work by non-police risk management organizations in the interests of meeting their own specific needs. ${ }^{8}$

\section{Limitations}

Nonetheless, this three-part sequential model very quickly reveals its limitations in respect of many of our empirical observations. For example, if we pursue the prehistory of modern road policing during the between-wars period, we find that the insurance companies and automobile manufacturers imposed much more than simple knowledge requirements on local police forces; the latter were also required to 'manage' to 'really' reduce the road risk. For the two groups with common interests, it was important that the public should not equate the car with a death machine and so resort to alternative means of transport (McShane 1997). Prior to the cognitive, political and industrial furore triggered by Ralph Nader's (1965) book, Unsafe at Any Speed, ${ }^{9}$ American car makers had steadfastly refused to take any design and manufacturing measures to render their cars safer, on the grounds that this would push prices up to unacceptable levels (Eastman 1984). ${ }^{10}$ In addition, a purely private-sector, insurance-based regulation of road risk was unthinkable at the time: the risk of serious accidents was so high that insurance for bodily harm was neither compulsory nor affordable for motorists. Thus, the development of the car society necessarily called for less risk taking on the part of drivers; and the two interest groups were extremely keen to see the police do their traditional job of traffic law enforcement on the public highway.

\footnotetext{
${ }^{8}$ 'In this context of compliance-based law enforcement based on regulation and the scientific knowledge of risk, the police are transformed ... they are driven by the knowledge requirements of other institutions that engage in compliance policing' (Ericson and Haggerty 1997: 49).

${ }^{9}$ Working from road accident and epidemiological research (Haddon et al. 1964), the book demonstrated the importance of the 'car design factor' in the rate and gravity of road accidents. But Nader went further, with a scrupulous dissection of the way the road safety 'policy subsystem' (Jones and Baumgartner 2005) masked the role of the 'car design factor'.

${ }^{10}$ The argument 'Cars don't kill people, people kill people' is still invoked today by many manufacturers whenever the threat of imposing limits on car engines looms.
} 
In general terms, this means that Road Risk Policing (RRP) was not created by ignoring the traditional police identity; rather, it presented as a hitherto unexploited area for expression of this basic professional specificity. We shall come back to this, but let us say for the moment that what is involved is as much a 'policification' of road risk as a 'riskification' of the police. This nuance forces us to highlight a notable shortcoming of the three-part sequential model outlined above: it attributes the major transformations of police organizations (part 3 of the model) to factors external to the organizations themselves, despite the undeniable existence of internal considerations. However, before we go into this matter in the second part of the article, let us take a look at the overall pressures on police forces resulting from the development of the road risk society. Our analysis makes it clear that pressures do not necessarily cause transformations, and that when transformations occur, they do not necessarily fit with EH's contentions.

\section{The proliferation of risk owners and its consequences}

First, it must be remembered that in all so-called modern societies, widespread use of motorized vehicles - buses, trucks, cars, motorcycles, mopeds - triggers social processes of creation and development of road risks that cannot necessarily be encapsulated in a 'road safety' or 'traffic safety' thematic. In early-twentieth-century Australia, which is to say mainly in Sydney and Melbourne, the history of post-motorization road risk merges with that of the risk of an urban congestion hampering the country's economic progress. In France, Anne Kletzlen (2000) has shown that before the mid 1960s, the main road risk - the one that determined the content of the Highway Code-had to do with damage to roads caused by buses and trucks, and to a lesser extent with road accidents: these latter were perceived not as negative public health events, but as road traffic malfunctions. In New Zealand after the First World War, non-payment of the various road taxes by users - whether professionals or not-was considered a cardinal risk in that it endangered the financing and upkeep of road infrastructures in the already difficult context of a large territory with a small population (Spenlehauer 2005).

Behind the host of concrete forms road risk can take in a motorized society is the functioning of numerous actors we can describe as 'social problem owners' (Gusfield 1981). The group is a very diverse one: insurance companies, car manufacturers, departments of transportation, automobile clubs, temperance leagues, research centres, city councils, breath-analyser manufacturers, etc. They may be big or small, dynamic or lethargic. They interact symbolically, legally or in decision-making terms, and in a range of ways including alliances, conflict, allegiance, subordination and mediation. Their relationships change over time. Our research leads us to the assertion that the more motorized a society is, the more the owners of segments of road risk proliferate and the more their interaction complexifies the overall transformational effect resulting from the various demands they make on the police. There follow two illustrations of this.

In five, six or seven decades, we have moved from the simple original configurationthe emergence of modern road safety policing as the cat's paw of the insurance companies - to another, much more complex one in which road safety policing is contributing, slowly but surely, to a significant shrinking of the automobile insurance market. Apart from the few places where bodily harm insurance is a government 
monopoly - the Australian states of New South Wales and Victoria, New Zealand, Quebec, etc.- police and road policing no longer clearly serve the interests of the insurance business. True, checking operations by road traffic police cuts down insurance premium evasion in the same way that NYPD's 'transit cops' cut back the free riding that was long a scourge for the city's Metropolitan Transit Authority. It is also true the accident reports made out by traffic police still keep the insurance companies' actuarial departments busy to some extent; but, in the developed countries, in which there is now scarcely any increase in car numbers and traffic, a mechanical divergence exists between the insurance economy and public sector regulation of road safety via traffic policing. Driven by a host of road safety problems, owners and the gradual elevation of road safety to the status of a major national issue, traffic policing has little by little brought about a significant cut in road risk, and, by extension, in the number and gravity of accidents and the insurance companies' turnover.

Without subscribing to a kind of democratic otherworldliness, it can be fairly said that, over time, road risk policing has ultimately served a pluralistically constructed general interest to the point of undermining the private industrial interests that initially, in between-wars America, had begotten this sort of risk policing. The history of road safety policies in modern societies neatly exemplifies the gradual emergence of the extra-parliamentary 'round table' politics that Ulrich Beck (1994) urges on us as a way of adapting parliamentary democracy to the issues of the risk society.

Our next illustration is just what is needed to temper this exciting hypothesis. In another article (Hamelin and Spenlehauer 2006), we showed that the creation of the California Highway Patrol in 1929 met two objectives pursued by the State of California and its government. The first of these was improved road risk management: reduction of the number of accidents via standardized application of the California Motor Vehicle Act of 1915, etc. The second was to provide the State of California with a sovereign police body entrusted with law enforcement, surveillance and arrest of suspects in cases being handled by local and county police forces, plus gun control and other duties in every part of the state.

The situation can be recapped as follows: in a given society, the social and political objectification of road risk can provide the opportunity (Kingdon 1995) for a territorial government to transform the overall context of policing governance to its own advantage without the main aim being reduction of road risk or modification of police approaches to such reduction. In short, the transformational energy of road risk can be rechannelled and 'detransformationalized'. Moreover, the creation in 2000 of a Police Highway Patrol for rural areas in New Zealand ${ }^{11}$ and the refounding of the Mossos d'Esquadra in Catalonia (Spain) (Ferret et al. 2007) ${ }^{12}$ demonstrate that there is nothing historically or geographically exceptional about the situation-bending observed in California.

\footnotetext{
${ }^{11} \mathrm{~A}$ part of the hidden agenda was discreet implementation of 'soft' community policing strategies in economically depressed Maori areas.

${ }^{12}$ The presence of these police officers on the Catalan road network signals, symbolically and in concrete terms, that there is no longer any place there for the Guardia Civil (national military police force).
} 


\section{The Internal Impact of the Risk Society on Policing Organizations: Second Test}

We can recap the above in the form of two interlocking details to be added to the EH paradigm.

First, while the emergence of a road risk society has unquestionably transformed the world of policing, its impact cannot be reduced to the simple expansion of road risk knowledge work in the POs. Far from it. Taken as a whole and with all their historical implications, the new demands being made on policing organizations are the outcome of the fact that numerous actors see these organizations as agencies for the enforcement of democratically conceived and voted traffic laws; only certain actors see them as suppliers of information in the sense of institutional brokers of social information for unavowed reasons of (undemocratically coercive) social control. Thus, analysis of the social pressures on police organizations in terms of road risk management could conceivably re-establish the primary, progressive meaning of social control viewed as the capacity of a society for self-regulation. ${ }^{13}$

Next, the number and differing status of the road problem owners claiming the right to a role in the definition of police aims and contributing to making police organizations more permeable do not call into question the latter's original function as public-sector bodies working for the community as a whole. To put it simply, the POs are not becoming centres of calculation in the pay of those asking for services. If the impact of the demands made by the different owners of road risk implies a certain subjection of the policing system, this new relationship is broadly and firmly based on a view of the police as a public service: as the organic embodiment of the pursuit of the public interest or, as we have seen in the instance of the California Highway Patrol, an expression of reasons of state. Whatever the case, after its very private-specific-interests-oriented beginnings, the RRP provided by police organizations historically and ineluctably ends up by affirming its publicness (Bozeman and Bretschneide 1994). This is no anodyne matter if the police are hypothesized first as a very public organization, both in their relative independence of the economic authorities and their marked dependence on the political ones; and, second, as a body whose surveillance and protection of the public represents a potential source of biopolitics in the sense of a permanent technology for government intervention (Foucault 2008).

This is why we would now like to go more deeply into the issue of subjection with an account of our observations and analyses of how police organizations react to injunctions from private or public owners of road risk. In the interests of clarity, we focus solely on the road safety/public health aspect of road risk. Giving thought to what some authors call the 'resilient cop culture' (Punch et al. 2002) means having to try to resolve the following enigma: numerous studies and scientific experiments have shown that user compliance with the main elements of the traffic laws-blood alcohol levels, speed limits, seat belts, helmets-would radically diminish road risk (Armour 1984). The operational strategies and technology of intelligence-led traffic law enforcement-speed cameras, miniaturized hyper-accurate breathalysers, road accident geographic information systems, etc.-are known and readily accessible. All kinds of cost-benefit analyses have led to the conclusion that the implementation of such strategies based on

\footnotetext{
${ }^{13}$ For an excellent historical outline of how American social scientists explored this notion of social control in the first half of the twentieth century, cf. Ross (1984).
} 
the intensive use of this technology shows economic rates of return of several hundred per cent! But, even so, if we look at the worldwide road safety Olympics, the so-called 'models' of excellence continue to display relatively high levels of risk in absolute terms. The United Kingdom, one of the medal winners in the field, currently racks up a death rate per billion vehicle/kilometres traveled of around 6.7: at some 3,400 deaths per year, this is several times the number of voluntary homicides in the country. This basic enigma is crystal-clear evidence that in the world's governed zones, the police organizations involved in road risk are far from having become implacable disciplineand-punishment machines, even though the road risk society has long contained all the factors needed to make them so.

\section{Professional ethos and organizational filtering}

Replying to this fundamental question means drawing on the patiently built up corpuses of the French sociologist of police organizations, Monjardet (1994; 1996), and the American sociologist, Manning (1992). In a painstaking study of complex professional rationales, Monjardet proves that the introduction of change into a police institution is only possible if the profession sees them as beneficial in terms of material gain, status and symbolism. Manning reminds us of the obvious: that any introduction of technological processing of problems, however massive and sudden it may be, becomes an integral part of the POs' skilfully constructed social equilibriums.

Looking at the way available technology structures the POs in countries we have recently explored - England, Spain and France - we would say that a relative malleability is agreed to in return for a transactional-type model. Here, we return to the implications of Foucault's (1975) Discipline and Punish, admitting that there exists, in a form more or less diffuse according to the period, a biopolitical project for changing society. This project has to be orchestrated and technology, being an effective tool for POs working within this same society, can become intrusive; this is equally true for the post-modern democracies our analyses focus on.

And, yet, the project always fails partially. This partial failure cannot be put down to police rejection of technology, which, for a long time now, has clearly permeated the POs, especially in respect of road risk. Nor is the police ethos recalcitrant here: technology is professionally desirable because it boosts status. The partial failure takes place because we are dealing with police ways of working that modulate and cushion the impact of outside pressures in line with standards that have nothing to do with external performance criteria. As the PO retains sovereign power over moral and professional behaviour, agreement by police actors is filtered through the interests of the profession and the workings of its hierarchy.

To take one last historical example: an examination of the teaching programme at Northwestern University Traffic Institute (NUTI) shows that since 1934, the theoretical training about accident reporting has ruled supreme, taking as its model the classical investigation of criminal cases: establishing the facts, looking for a motive, finding witnesses, collecting evidence, etc. (Douthit 1992; Kreml 1954). Even under the pressure-strong because financially grounded-of American insurance companies, NUTI teaching reflected the traditional professional interests of the police, and this led to a clear degree of non-compliance in respect of insurer requirements. What happened was that the police profession made accident reporting more a matter of work by a 
police specialist (and no longer by a knowledge worker alienated from the results of his work). ${ }^{14}$ This explains why, today, in absolutely all the countries we have been to, nonpolice road safety specialists often accuse police officers of botching the filling of accident report forms. There exists, too, the sociological fiction that these organizations are manipulated from outside by future-oriented managerial techniques. Technology and the various potential outside manipulators have an impact only on the condition that they are parties to internal contractualization.

\section{Internal contracts around technology uses}

A twenty-first-century example of contractualization and of modulation of a road risk technology is available thanks to the apparent return to favour of road risk policingespecially in terms of staffing - in the joint policy of the British Home Office and the powerful Association of Chief Police Officers (ACPO). The adoption and, very recently, extensive use of Automatic Number Plate Recognition (ANPR) technology were based on studies showing that offenders and common-law criminals commit significantly more infractions of the highway code than the rest of the population. The outcome was the setting up of a national infrastructure comprising, at county level, mobile traffic police units - cars and trucks - equipped with ANPR and connected by wifi to the National Police Computer, the primary aim being surveillance (via detection) and harassment (via fines, vehicle confiscation, etc.) of offenders and criminals either known or under suspicion. Officially presented as a win-win strategy for crime policing and road safety, the ANPR system means de facto indulgence towards millions of 'honest' British road users, in that it uses police manpower formerly occupied with speed or DUI deterrence, awareness campaigns in schools, etc.

A further example of mechanization that a priori fits better with EH's model is the use of automatic fixed speed cameras systems in the United Kingdom, France and Australia. ${ }^{15}$ With implementation of these systems due mainly to pressure from the departments for transport in these countries, we are faced here with implacable road risk policing machines - which function to all intents and purposes without police officers. Overall, installation of these systems demonstrates that police organizations can react to external pressures without being transformed. At a more subtle level, however, it should be noted that the very small number of officers involved in the management of these systems - to ensure the ongoing legality of their functioning-help the POs to use the systems as surveillance tools in the framework of judicial enquiries. We are dealing here with a quite definitely transactional rationale as opposed to one of subjection of the police. And, lastly, the handful of officers involved give the police organization they belong to a vital specialist status regarding the (undeniable) political risks run by the governments that put the systems into operation.

In the final analysis, and whatever the system involved, the POs retain significant autonomy and centrality. This modulation of technology appears most often as part of an economy of relationships between hierarchy levels. For police chiefs, then, the aim is

\footnotetext{
${ }^{14}$ For a better understanding of why a penal system forces police traffic officers to become experts in 'road public order' rather than simple (knowledge) workers, see Pollner (1987).

${ }^{15}$ The fact that these systems are run either within a decentralized framework (i.e. UK counties' 'speed-camera partnerships') or on a centralized state-owned basis (as in France or New Zealand) is indifferent for our argument.
} 
often to regain power over internal personnel by offering in exchange the ease of work made available by technological tools: for example, a better fit between professional and private life can be made possible by improved governability of work. It should be underlined, however, that in all these situations, the information manufactured by police officers rarely moves outside the police family, and within it is subject to constant negotiation, for the tools are also virtually means of monitoring and sanctioning policing performance. Thus, the upper echelons bring very cautious support to the introduction of new technology into police work, for fear of finding themselves cut off from the grassroots workers who have a monopoly of the raw data. And, so, where road risk is concerned, there is absolutely no reason for automatically confusing police use of information technology with Taylorization and alienation of the results of police work for the benefit of non-police institutions.

\section{Working for legitimacy/relations with the public}

In contrast with the isolationist, monocultural image typified by the recurring figure of the crime fighter, the road traffic policeman is not an automaton that notes infractions and grimly writes tickets. In a democracy, the everyday legitimacy granted to the police by a large part of the community is a sine qua non of police functioning, not to say of its continuing existence. And, given the core place of road transport in our societies, this granting of legitimacy can only happen, at least in part, if the POs send out convincing signals to the effect that traffic law enforcement is practised with discretion and is not a blind, implacable, brutal machine. In the absence of such signals, relations between police and the population go downhill (Wilson and Chappell 1971), with consequences ranging from a fall in the clear-up rate to deterioration of the mental health of police officers. In 'second modernity' societies, there exists a deep-rooted culture of permanent challenge to the validity, relevance and honesty of traffic law enforcement: 'You're just making money for the government'; 'Why aren't you out catching the real criminals?'; 'Don't try and tell me that sign's in the right place'; 'It's thanks to you people lose their licences and their jobs'; and 'Why don't you book all those guys with straight-through Harleys who keep me awake every night?'. These are just five performative examples among thousands of this quasi-universal attitude.

Faced with this stance ${ }^{16}$ - one all the stronger for being shared by a lot of police officers - the police organization has no choice but to come up with compromises; and so we find the big chief putting out policy statements about 'zero tolerance for marijuana smokers at the wheel', while, at the same time, officers on the street are showing a greater degree of tolerance (Gusfield 1975). At operational level, strategies become institutionalized, which limits the repressive side of traffic law enforcement, often in favour of deterrence (for example (in Britain), not increasing the number of speed cameras, but increasing the number of sites where they can be installed), or prevention (issuing written warnings rather than tickets), or educational programmes. Implementation of these a-repressive strategies goes hand in hand with demands,

\footnotetext{
${ }^{16}$ See Purenne (2005) for a description of how the introduction of road safety into Montreal's municipal community policing policy kicked off a bottom-up process of transformation of road policing in the city. This article backs up our earlier comments on proliferation of road risks and their owner-managers (Hamelin and Spenlehauer 2005a).
} 
notably in terms of police officer skills, that can change the public face of the POs in many different ways. ${ }^{17}$

\section{Conclusion}

Given the EH paradigm as summed up in their conclusion, together with their multiple invocations of Foucault, we shall begin by quoting a warning from the philosopher himself on the interpretation of his book, Discipline and Punish (1977): 'The automatic nature of power - the mechanical character of the systems in which it takes shape-is absolutely not the book's thesis .... To study the way in which attempts have been made to rationalize power ... and to demonstrate the importance of the part played by the theme of the machine, the gaze, surveillance, transparency, etc., is not to say that power is a machine, nor that such an idea is born mechanically!' (Perrot 1980: 34). This was Foucault's reply to the historians who accused him of shoring up the book's thesis with selective, not to say biased, use of archival material.

What the author of Discipline and Punish has to say is simple and seems to us to fit with our criticisms of the EH paradigm. Surveillance projects undeniably exist in modern societies; but they are destined either to remain projects or to take shape only partially, as demonstrated by completed historical experiments. ${ }^{18}$ Such projects are real, but do not cover the full reality of the situation. By focusing their argument on plans for the subjection of POs rather than their day-to-day workings, $\mathrm{EH}$ seem to be using the Foucault paradigm to justify an ideal typical system of knowledge generating, without real empirical basis, one excessively security-oriented conception of 'state power' and politics.

Analysis of the implementation of projects designed to transform police forces into panoptic bodies shows that these projects are always paralleled by contradictory, traditional law enforcement projects targeting the risk to be dealt with. The subjection projects are centrifugal in the sense that they fuel the disintegration of the immanence of the POs. By contrast, the demands of traditional monopolistic law enforcement that are indissociable from these projects are centripetal in character. By making a moderate law enforcement effort in a new risk field, the POs succeed remarkably well in breaking

\footnotetext{
${ }^{17}$ Thus, since 1995, an inadequate grasp of Spanish disqualifies candidates from the California Highway Patrol Academy entrance exam, bringing a major change in the make-up of the force.

${ }^{18}$ One example is the Paris police force, independent of the city's system of justice that Louis XIV established by decree in 1667. In her perceptive dissection of this critical moment in the history of the French police, Hélène L'Heuillet (2001) shows clearly that, prior to that year, the Paris police, as an arm of the judiciary, identified (potential) disrupters of public order, arrested them and handed them over to the courts. After 1667, with a view to 'political anticipation', the 'Paris Lieutenant for the Police' set up on the king's behalf a system of monitoring and surveillance of the entire Paris population and its activities, wherever these might take place: 'The king knows everything and can act surely and promptly.' It should be pointed out, however, that Louis XIV was not behaving like today's owner-managers of risks, for he required the police force to make itself an intelligent panoptic political watchdog. This 'new' Paris police certainly had a contingent character, given that without the decree of 16 March 1667, it might never have existed. But this contingency was quickly replace by a marked immanence, for the force's daily activities were decided on and organized from within, via multiple transactions with the royal authorities, the justice system and the people. Three centuries later, the absolute monarch has been replaced by governments that, in the democratic give and take of second modernity societies, cannot turn a deaf ear to the demands of a large number of owner-managers of risks whose aim is to align the panoptic capacity of police organizations with their own interests. Moreover, in the risk society, owner-managers of risks, unlike Louis XIV, possess an expertise independent of that of the police, which allows them to formulate precise demands regarding the configuration of police panopticism. Lastly, second modernity societies bristle with information technology likely, according to EH, to robotize and dehumanize the functioning of the planned police panopticism and render it, in contrast with the Paris Lieutenant for the Police, unintelligent and servile.
} 
free of the demands for compliance the owners seek to impose on them. All things considered, then, while police forces change with the proliferating dynamics of disciplinary regulation that characterize risk societies, they nonetheless succeed in maintaining their core status within these dynamics while remaining themselves, namely basically as described by Bittner. This key role means they are now especially well placed to face and above all digest the multiple pressures they are subjected to. This is why we cannot consider risk-oriented police forces as embodying the rebirth of a maximum security society (Marx 1988) - at least not without making it clear that the configuration is latent or virtual. At present, there is still little empirical evidence in support of EH's panoptical policing thesis.

It is true that the proliferation of risk regulation projects opens up new potential fields of police intervention, not only on the margins of society, but at its very core. However, since the police have limited resources, they cannot move into all these fields and may even attempt to influence governments to keep them closed via legislation or regulation. Police forces are compelled to make strategic choices in the management of their risk portfolios, and there exists in all these portfolios a major risk that EH neglect because it is in no way post-modern and its owners, as they see it, do not deserve actor status: the everyday risk of Hobbes's 'war of all against all'. Thus the EH paradigm contains an overtly facile concept that merits our mistrust when we look into contemporary policing issues: the facile concept of POs - and, by extension, 'state' action - as subject to a special system of command that is itself symptomatic of a thought mode made dominant by an inbuilt, exaggerated level of privilege that is, by its very nature, illegitimate.

Loader and Walker (2006) have already pointed out the prejudices underlying the state scepticism that determines Anglo-American criminological approaches. ${ }^{19}$ As our contribution to this transatlantic dialogue, we suggest that POs be seen as social agencies that are public in their growing dependence, not only on economic authorities with the weight of the political authorities behind them, but, above all, on the community from which they draw the ultima ratio of their legitimacy. This approach would take account of static connotations of the terms 'state' and 'police', not widely accepted in a sociological approach. The socio-political context in which the activity of the hypersocial POs takes place would gain by being perceived not as an imaginary city in which each individual would a priori have a clearly assigned place according to a crypto-functionalist view of things, but as 'a road, or even a road network, on which active individuals circulate in pursuit of what Tocqueville called "self-interest rightly understood" (Pavel 2008: 56). We would no longer attribute to the police-and its supposed risk-regulating puppet masters - the task of making sure that the 'little' actors 'stay in their place', but rather that of regulating mass traffic and the risks associated with it. Far from hampering transactions between private individuals, and the activity of public interest clubs, the 'police' would make them possible within certain elastic, future-friendly limits. As it happens, the traffic metaphor used by Pavel (2008) fits with Loader's invocation of neutralist philosophy (Loader and Walker 2006: 186): it is as if 'politics', the 'state' and the 'police' are meta-active and neutral or, more exactly, aiming at neutrality in relation to activities that, while private, remain vital to the sound functioning of all this.

\footnotetext{
${ }^{19}$ They identify four variants of this state scepticism: the state as meddler, partisan, cultural monolith and idiot. See also Ferret (2004).
} 
The upshot is that the theses of minimal public policing are automatically undermined: how could one design a freeway with no traffic rules or signposting? In addition, the new world of networks and physical and social mobility is perfectly compatible with an infinite range of political arrangements and notions of the public good. This is why it can also be justifiably maintained that the POs enjoy a centrality that is problematic, worrying and potentially destructive of freedom. At the same time, it cannot be ignored that they face a categorical imperative to guarantee the protection of the common good: security as a thick public good (Loader and Walker 2006: 183). Thus, this centrality certainly exists: it is maltreated and, at the same time, renegotiated under the influence of multiple centrifugal and centripetal forces in a very transactional world. In fine, we propose the somewhat provocative hypothesis that EH's notion of panoptical policing should be taken as a theoretical innovation that, far from eliminating Bittner's paradigm, enhances it with a new force.

\section{Funding}

Either the 'Direction de la sécurité et de la circulation routières' (French Department of Transport) in the framework of the third 'Programme national de recherche et d'innovation dans les transports' (PREDIT) or via the 'Institut national des hautes études en sécurité' (IHNES) of the French ministry of Interior, or the Ministry of Research, the 'Institut national de recherche sur les transports et leur sécurité' (INRETS)

and the 'Centre national de la recherche scientifique' (CNRS) joint research program 'action concertée incitative (ACI) "Sécurité Routière et Société"”.

\section{Acknowledgement}

Special thanks to Clifford Shearing for his careful reading and pertinent remarks.

\section{REFERENCES}

Armour, M. (1984), 'A Review of the Literature on Police Traffic Law Enforcement', Australian Road Research Board, 14: 17-25.

BARDET, F. (2008), 'Quand les constructeurs automobiles façonnent la sécurité routière: la médiatisation des accidents de la route aux Etats-Unis', Réseaux, 147: 87-113.

Beck, U. (1994), 'The Reinvention of Politics: Towards a Theory of Reflexive Modernization', in U. Beck, A. Giddens and S. Lash, eds, Modernization: Politics, Traditions and Aesthetics in the Modern Social Order, 1-55. Cambridge (UK): Polity Press.

- (2001), La société du risque. Paris: Aubier.

Bernardin, S. (2006), 'La production de statistiques comme vecteur de légitimité: l'avènement du National Safety Council aux Etats-Unis, 1923-1947', in M. Guilbot, ed., L'accident de la route: comprendre pour mieux agir, 53-76. Arcueil (France): Les Collections de l'INRETS.

Bittner, E. (1970), The Function of the Police in Modern Society: A Review of Background Factors, Current Practices and Possible Role Models. Washington, DC: Gvt Printing Office.

Bozeman, B. and Bretschneider, S. (1994), "The "Publicness Puzzle" in Organization Theory: A Test of Alternative Explanations of Differences between Public and Private Organizations', Journal of Public Administration Research and Theory, 4: 197-223. 
Brodeur, J. P. (2001), 'Le travail d'Egon Bittner: Une introduction à la sociologie de la force institutionnalisée', Déviance et Société, 25: 307-23.

- (2003), Les visages de la police. Montréal: Presses Universitaires de Montréal.

Carnis, L., Hamelin, F. and Spenlehauer, V. (2006), Les polices de la route: Une approche comparée Etats-Unis, Nouvelle Galles du Sud et Nouvelle-Zélande, 269. Arcueil (France): Les collections de l'INRETS.

Douthit, N. (1992), 'August Vollmer, Berkeley's First Chief of Police, and the Emergence of Police Professionnalism', in E. Monkkonen, ed., Policing and Crime Control, Part 3, 92119. Munich, London, New York, Paris: Saur.

Eastman, J. W. (1984), Styling versus Safety: The American Automotive Industry and the Development of Automotive Safety, 1900-1966. New York: University Press of America.

Emsley, C. (1991), 'Mother, What Did Policemen Do When There Weren't Any Motors? The Law and the Regulation of Motor Traffic in England, 1900-1939', in P. Robert, ed., La Création de la Loi et ses Acteurs: l'exemple du droit pénal, 149-78. Onati: Onati Proceedings.

Ericson, R. V. and Haggerty, K. D. (1997), Policing the Risk Society. Toronto: University of Toronto Press.

Ferret, J. (2004), 'The State, Policing and "Old Continental Europe”: Managing the Local/ National Divide', Policing and Society, 14: 49-65.

Foucault, M. (1977), Discipline and Punish, tr. Alan Sheridan. New York: Pantheon.

- (2008), The Birth of Biopolitics: Lectures at the Collège de France (1978-1979), tr. Graham Burchell Basing stoke (Eng.):Palgrave Macmillan.

Gusfield, J. R. (1975), 'The (F)Utility of Knowledge? The Relation of Social Science to Public Policy toward Drugs', Annals of the American Academy of Political and Social Sciences: Drugs and Social Policy, 417: 1-15.

-(1981), The Culture of Public Problems: Drinking-Driving and the Symbolic Order. Chicago: The University of Chicago Press.

Hacking, I. (2000), The Social Construction of What. Cambridge, MA: Harvard University Press.

Haddon, W. Jr, Suchman, E. A. and Kuein, D. (1964), Accident Research: Methods and Approaches. New York: Harper \& Row.

Hamelin, F. (2006), 'Naissance d'une police: Comment la police de la route est devenue une institution légitime aux Etats-Unis', Genèse, 63: 88-107.

Hamelin, F. and Spenlehauer, V. (2005a), 'Police de la route et police communautaire sont-elles compatibles? Premiers éléments de réponse à partir des cas californiens et néozélandais', colloque international francophone: la police et les citoyens, Ecole nationale de police du Québec, Nicolet (Canada)available online at www.cicc.umontreal.ca/ policecitoyens/index.htm.

$-(2005 b)$, 'Polices de la route et police sur la route', Les Cahiers de la Sécurité Intérieure, 58 : 9-28.

(2006), 'Road Policing as a State Tool: Learning from a Socio-Historical Analysis of the California Highway Patrol', Policing and Society, 3: 261-84.

-(2008), 'L'action publique de sécurité routière: Entre rêve et réalisme', revue Réseaux, 147: 49-86.

Jones, B. D. and Baumgartner, F. (2005), The Politics of Attention: How Government Prioritizes Problems. Chicago: The University of Chicago Press.

Kellens, G. ANd PÉrez-Diaz, C., eds (1997), Le contrôle de la circulation routière dans les pays de la CEE. Paris: l'Harmattan. 
Kingdon, J. (1984), Agendas, Alternatives, and public policies, Newyork: Harper-collins. Kletzlen, A. (2000), L'automobile et la loi: Comment est né le Code de la route. Paris: l'Harmattan. Kreml, F. M. (1954), 'The Specialized Traffic Division', Journal of the American Academy of Political and Social Science, 291: 63-72.

Latour, B. (1987), Science in Action. Cambridge, MA: Harvard University Press.

L'Heulllet, H. (2001), Basse Politique, Haute Police. Paris: Fayard.

Loader, I. and Walker, N. (2006), 'Necessary Virtues: The Legitimate Place of State in the Production of Security', in J. Wood and B. Dupont, eds, Democracy, Society and the Governance of Security, 165-95. Cambridge: Cambridge University Press.

Manning, P. K. (1992), 'Information Technology and the Police', in M. Tonry and N. Morris, eds, Modern Policing, 349-98. Chicago: Chicago University Press.

Marx, G. T. (1988), 'La société de sécurité maximale', Déviance et Société, 12: 147-66.

McEnnis, L. J. (1952), 'The Background and Development of the Traffic Institute of Northwestern University', Journal of Criminal Law, Criminology and Police Science of Northwestern University, 42: 663-73.

McShane, C. (1997), The Automobile: A Chronology of its Antecedents, Development, and Impact. Westport: Greenwood Press.

Monjardet, D. (1994), 'La culture professionnelle des policiers', Revue Française de Sociologie, 3: 393-411.

- (1996), Ce que fait la police: Sociologie de la force publique. Paris: La Découverte.

NADER, R. (1965), Unsofe at any speed, the designed-in dangers of the American automobile, Newyork: Grossman

Ocqueteau, F. (2004), Polices entre Etat et Marché. Paris: Presses de Sciences Po.

OECD (1990), L'assurance automobile et la prévention des accidents de la route. Paris.

Pavel, T. (2008), 'Lettre à Vincent Descombes', Philosophie du jugement politique, 49-57. Paris: Seuil, Point.

Perrot, M., ed. (1980), Recherches sur le système pénitentiaire au XIXème siècle: débat avec Michel Foucault. Paris: Seuil.

Pollner, M. (1987), Mundane Reason: Reality in Everyday and Sociological Discourse. Cambridge (UK): Cambridge University Press.

Punch, M., Vijver (van der), K. and Zoomer, O. (2002), “'COP”: Developing Community Policing', The Netherlands, Policing (An International Journal of Police Strategies E Management), 25: 60-79.

Purenne, A. (2005), 'La relation police/citoyens à Montréal au prisme de la lutte contre l'insécurité routière', Les Cahiers de la Sécurité Intérieure, 58: 101-20.

Ross, D. (1984), 'American Social Science and the Idea of Progress', in T. Hasskell, ed., The Authority of Experts: Studies in History and Theory, 157-75. Bloomington: Indiana University Press.

Spenlehauer, V. (2005), 'La police de la route néo-zélandaise est un laboratoire', Les Cahiers de la Sécurité Intérieure, 58: 51-74.

Wilson, P. R. and Chappell, D. (1971), 'The Effects of Police Withdrawal from Traffic Control: A Comparative Study', Journal of Criminal Law, Criminology and Police Science, 61: 567-72. 